\title{
Gabriel A. Almond, Doris A. Graber, Malcolm E. Jewell and Thomas E. Mann
}

Gabriel A. Almond, Doris Graber, Malcolm Jewell, and Thomas E. Mann will be honored for their significant contributions to the political science profession and the American Political Science Association at the 1999 Honors Reception, Wednesday, September 1, in conjunction with the APSA Annual Meeting in Atlanta.

A leader in the social sciences for over forty years, Gabriel A. Almond is being honored for his contributions to the advancement of political science research broadly, comparative politics particularly, and his service to the profession through this Association.

Almond's scholarly achievements directly contributed to the development of theory in comparative politics and brought together work on the developing areas and Western Europe. His initiative changed the focus of comparative politics, creating a separate social science subfield. His seminal work with Sidney Verba on civic culture in five countries, The Civic Culture (1963), is a landmark in the literature of comparative politics. The questions it raises about the relationship between the attitudes of citizens and the functioning of democratic states have endured.

A fellow of the American Academy of Arts and Sciences and the National Academy of Sciences, and a former chair of the Social Science Research Council, Almond served the Association as a council member, vice president, and president. During his presidency, the Association first considered how to encourage the development of political science abroad, began developing a professional code of conduct, and moved to Washington, DC. Almond has consistently, effectively, and generously supported the Association and its programs. His commitment to enriching the dialogue within the discipline is evidenced by his efforts, along with Sidney Verba, to endow the Harold D. Lasswell Symposium, a triennial Annual Meeting plenary session at which three outstanding political scientists address a common theme.

Almond has played a unique role in recording the intellectual history of the discipline and commenting on the state of the discipline. His chronicles of the methodological and ideological developments within the profes- sion have helped preserve the discipline's history for successive generations of political scientists.

Doris A. Graber, a pathfinder in the area of political communication research, will be recognized for her contributions to the development of the political communication field and for her extraordinary service as a teacher, mentor, editor, and association officer.

Graber's research, which addresses many of the major questions in the field of political communication and fundamental questions about the role of the media in the political process, helped establish an agenda for contemporary political communication research. Her efforts helped establish political communication as a unique subfield within the discipline. She has extended the boundaries of the discipline through her interdisciplinary research.

Graber began her professional life as a journalist; later she became an editor for Harper and Row. Since then, she has held several academic positions, including her current position at the University of Illinois, Chicago; continued her work as an editor, most recently as the first editor of Political Communication; and served many professional associations. Graber entered professional service at a time when women were absent from the leadership of professional organizations. She served as president, vice president, council member, program chair, editor, editorial board member, and committee member of numerous organizations, including the American Political Science Association, its Organized Section on Political Communication, the Midwest Political Science Association, the International Communication Association, and the International Society for Political Psychology.

Graber's service to APSA and other professional organizations has strengthened the profession and her leadership of and contributions to the field of political communication have enriched the discipline.

Malcolm E. Jewell will receive the Goodnow Award in recognition of his contributions to the field of legislative politics, his service to the profession, and his dedication to documenting the development and growth of the discipline through the APSA-Pi Sigma Alpha Oral History Project. A leading scholar of legislative politics, Ameri- 


\section{to Receive 1999 Goodnow Award}

can political parties, and elections, Jewell spent his career teaching at the University of Kentucky, where he was recognized for outstanding contributions to graduate education and named a distinguished professor.

Jewell has served the profession with distinction at all levels, serving as president of the Midwest, Southern and Kentucky political science associations. In addition to his terms as an APSA Council member and as a member of several APSA committees, Jewell edited a number of scholarly publications, and sat on the editorial board of many others, among them the American Political Science Review.

As director of the APSA-Pi Sigma Alpha Oral History Project, Jewell made his unique contribution to the profession. Jewell assumed leadership of the project in 1987 , continuing the work of previous directors to record the history of political science. His leadership saw the publication of $\mathrm{Po}$ litical Science in America: Oral Histories of a Discipline (1991), a collection of excerpts from interviews with some of the discipline's most distinguished scholars, which Jewell edited with Michael Baer and Lee Sigelman.

Jewell recognized the importance of chronicling the expansion of the profession to include African Americans and worked to secure funding from the Ford Foundation to develop an oral history project focusing exclusively on the contributions of African American political scientists. Jewell's commitment has guaranteed that the historical record of the pioneers of contemporary political science are preserved for successive generations.

Thomas E. Mann is being recog nized for the efforts he made to revitalize the Association during his term as executive director from 1981 to 1987 and for contributions to the public understanding of congressional politics. A former APSA Congressional Fellow, Mann worked at the Association for seventeen years as director of the Congressional Fellowship Program, assistant director and executive director, before becoming director of the governmental studies program at The Brookings Institution. During his tenure as executive director, Mann strengthened the Association and made it more useful to its members.

Mann oversaw the development of Organized Sec- tions, the creation of associate memberships, and changes to the Annual Meeting that allowed greater numbers of political scientists to participate each year. In the seventeen years since Organized Sections were introduced, they have become a vital and vibrant part of the Association. Thanks to Mann's efforts, APSA has one of the most comprehensive collections of data on its discipline among social science associations. After moving to Brookings, he continued to serve the Association as a program chair, chairman of the CFP Advisory Committee, and member of the APSR editorial board.

Since joining Brookings, Mann has maintained his own scholarly work while encouraging the work of others. His studies of the American political system are among the best the profession has to offer, and his commentary on current political events-whether on radio, on television, or in print-is highly regarded.

The APSA Council established the Frank J. Goodnow Award in 1996 to honor the contributions of individuals to both the development of the political science profession and the building of the Association. Frank J. Goodnow, the Association's first president, exemplified the public service and volunteerism that this award represents. He was the first of many who voluntarily contributed an extraordinary amount of their time, energy, and attention to building a dynamic learned profession. The Goodnow Award was given for the first time at the 1997 Annual Meeting and presented to Pendleton Herring, Roberta Sigel, Max Kampelman, and Eugene Eidenberg. The 1998 recipients of the Goodnow Award were Walter E. Beach, Warren Miller, and Jewel Prestage.

Nominations for the 2000 Goodnow Award, to be presented at the 96th Annual Meeting in Washington, DC, August 31-September 3, 2000, are being accepted until November 1, 1999. The Endowments Committee will select nominees for final approval by APSA's Administrative Committee. To submit nominations, including self-nominations, please send a letter and a copy of the nominee's curriculum vitae to Laura Barrantes, APSA, 1527 New Hampshire Avenue, NW, Washington, DC 20036-1206. For questions about the nomination process, please call (202) 483-2512 or email lbarrantes@apsanet.org. 